\title{
The history of neurosurgery at the University of Sao Paulo
}

\author{
A história da neurocirurgia na Universidade de São Paulo \\ Manoel Jacobsen Teixeira", Eberval Gadelha Figueiredo², Mario Augusto Taricco², José Pindaro P. Plese ${ }^{2}$, \\ Camila Flores ${ }^{3}$, Saulo A. Teixeira ${ }^{4}$, José Luzio²
}

\begin{abstract}
The history of neurosurgery at University of São Paulo comes from 1918, since its origins under the Department of Neurology from Chair of Psychiatric Clinic and Nervous Diseases. Professor Enjolras Vampré was the great inspiration for such medical specialty in the State of Sao Paulo. In 1929, the first neurosurgical procedures were performed in the recently (at time) organized Section of Neurosurgery. The official inauguration of the Division of Functional Neurosurgery occurred at June 1977, with the presence of worldwide well-known neuroscientists. The division suffered a deep streamlining under the leadership of Professor Raul Marino Jr., between the decades of 1990 and 2000 . At this time, it was structured with the sections of neurological surgery, functional neurosurgery and neurosurgical emergency. Since 2008, Professor Manoel Jacobsen Teixeira is the Chairman of the Division and has provided the Division with the best available technological resources, performing more than 3,000 surgeries a year and training professionals who will, certainly, be some of the future leaders of brazilian neurosurgery.
\end{abstract}

Keywords: history, faculty, medical schools, neurosurgery.

\section{RESUMO}

A história da neurocirurgia na Universidade de São Paulo remonta a 1918, quando surge sob o Departamento de Neurologia da cadeira de Clínica Psiquiátrica e Doenças Nervosas. O Professor Enjolras Vampré foi o grande inspirador da especialidade no estado de São Paulo. Em 1929, foram realizadas as primeiras intervenções neurocirúrgicas na então recentemente organizada Seção de Neurocirurgia. A fundação oficial da Divisão de Neurocirurgia Funcional data de junho de 1977 e contou com a participação de diversos cientistas de renome internacional. A Divisão passou por profunda reorganização sob a direção do Professor Raul Marino Jr. entre as décadas de 1990 e 2000 , quando foi estruturada com os setores de neurocirurgia geral, neurocirurgia funcional e emergência neurocirúrgica. Desde 2008, o Professor Manoel Jacobsen Teixeira é responsável pela Divisão, que conta com os melhores recursos tecnológicos disponíveis, realizando mais de 3.000 cirurgias por ano e formando profissionais que certamente serão futuros líderes na neurocirurgia brasileira.

Palavras-chave: história, docentes, escolas médicas, neurocirurgia.

Neurosurgery at the school of medicine at the University of Sao Paulo (USP) was established within the Department of Neurology from Chair of Psychiatric Clinic and Nervous Diseases of USP School of Medicine, founded in 1918, which first Chairman was the internationally renowned eminent psychiatrist and psychologist Dr. Francisco Franco da Rocha (Figure 1A).

In March of 1925, Professor Enjolras Vampré (Figure 1B) was appointed as the Head of the Department of Neurology ${ }^{1}$. At this time, neurology lectures were held in the First Ward of Medicine of the Santa Casa de Misericórdia of São Paulo. In 1926, following a reformulation at the School of Medicine, the discipline started to be called Neuriatric and Psychiatric Clinic.

Professor Enroljas Vampré was the truly inspiring of the neurosurgery in the State of São Paulo. He acctually induced in his disciple, Dr. Carlos Gama Rodrigues (Figure 1C), the surgical interest for the nervous system and advised him to carry out a traineeship with Dr. Harvey Cushing in the United States of America. Thanks to Dr. Carlos Gama

${ }^{1}$ Professor, Chairman, Divisão de Neurocirurgia, Universidade de São Paulo, Sao Paulo SP, Brazil;

${ }^{2}$ Associate professor, Divisão de Neurocirurgia, Universidade de São Paulo, Sao Paulo SP, Brazil;

${ }^{3}$ Student, Escola de Medicina, Universidade Nove de Julho, Sao Paulo SP, Brazil;

${ }^{4}$ Student, Escola de Medicina, Universidade Federal da Paraíba, Joao Pessoa PB, Brazil.

Correspondence: Eberval Gadelha Figueiredo; Disciplina de Neurocirurgia, Faculdade de Medicina, Universidade de São Paulo; Rua Enéas Carvalho de Aguiar 255 - $5^{\circ}$ andar; 05403-900 São Paulo SP - Brasil; E-mail: ebgadelha@yahoo.com

Conflict of interest: There is no conflict of interest to declare.

Received 19 August 2013; Accepted 27 August 2013. 


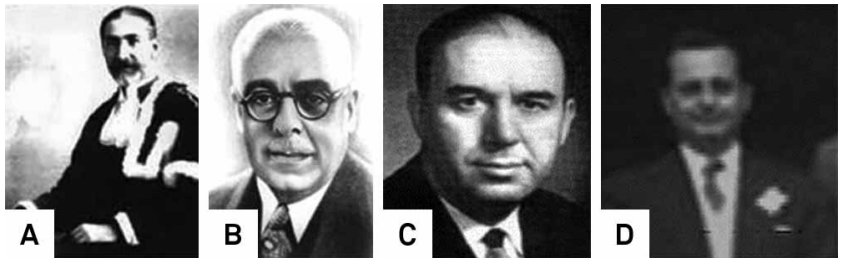

Figure 1. Francisco Franco da Rocha (A), Enjolras Vampré (B), Carlos Gama Rodrigues (C) and Rolando Ângelo Tenuto (D).

Rodrigues the neurosurgery in the USP was introduced in 1929 when the first neurosurgical interventions were performed in the recently organized Section of Neurosurgery at Neuriatric and Psychiatric Clinic. However, with the precocious death of Professor Enroljas Vampré, the Chair was unfolded: Psychiatric clinic (headed by the Professor Dr. A. C. Pacheco e Silva) and Neurological Clinic (headed by the Professor Dr. Adherbal Tolosa) in December of $1938^{1}$.

In 1942, Professor Dr. Rolando Ângelo Tenuto (Figure 1D) replaced the Professor Carlos Gama Rodrigues as the Head of the Section of Neurosurgery. Professor Rodrigues resigned to be the Chairman of Neurology at the School of Medicine of Bahia. The team led by Professor Tenuto projected and introduced advanced neurosurgical concepts. This advancement was due also to the work of other neurosurgeons including Dr. Roberto Araujo, Dr. José Zaclis, Dr. Sylvio de Vergueiro Forjaz, Dr. Leonardo Messina and Dr. Carlos de Lucia ${ }^{2}$.

In the beginnings of 1945, the Neurological Clinic, and consequently neurosurgery, began decisive phase of its history while being transferred to the Hospital das Clínicas of University of São Paulo under the leadership of Professor Adherbal Tolosa as well as his effective assistants Professors Oswaldo Lange and Oswaldo Freitas Julião.

At this time, the installations of the Neurological Clinic were distributed on several floors; the wards and the library were located on the second floor, while the outpatient department, Theater, Assistants Meeting Room and Unity of Electroencephalography were allocated on the sixth floor. The Section of Neurosurgery was incorporated to the Surgical Center, on the eighth floor along with the Department of Neuroradiology, and the cerebrospinal fluid laboratory, at the seventh floor. In 1952, following the move of the Orthopedics and Traumathology Department to its own Institute, the Neurological Clinic was established definitely in the Western block and next to the main arm of the Central Institute.

In 1952, after decision of the Administration Council of the Clinics Hospital which organized the Emergency in neurosurgery, now subordinated to the Neurological Clinic, were hired Dr. Sylvio de Vergueiro Forjaz, Dr. Leonardo Messina, Dr. Norberto Augusto Longo, Dr. Hamleto Santocci, Dr. Gabriel Rosso Massagochi Gotto, Dr. Ernani Lotugo, Dr. João Teixeira Pinto, Dr. Carlos Zamot, Dr. Darcy de Freitas Veluttini and Dr. Oswaldo Ricciardi Cruz.
Developments in neuroradiology was grown at the same time due to the outstanding work of Dr. José Zaclis, making possible the organization of the neurosurgical activity and formation of several disciples who became important national and international neurosurgeons. In 1948, Professor José Zaclis presented his $\mathrm{PhD}$ thesis and in 1968, Dr. Gilberto Guimarães Machado de Almeida obtained the title of Associate Professor.

On July $14^{\text {th }}, 1973$ the pioneer neurosurgeon, Professor Rolando A. Tenuto died of serious neurological disease. Since his lay-off due to the disease and after his death, Neurosurgery, between 1970 and 1974, was under the regency of Professor José Zaclis (Figure 2A). Besides developing neuroradiological procedures in our institution, he introduced the stereotactic method and he was the idealizer of numerous proceedings in the image area.

Functional Neurosurgery was idealized and organized by Dr. Públio Salles Silva in 1961, in the Institute of Psychiatry of the Hospital das Clínicas of University of São Paulo.

In 1971, Professor Raul Marino Jr. collected the concepts and the technological proceedings that were introduced in the neurosurgery worldwide and reorganized Functional Neurosurgery in the Psychiatric Clinic of Hospital das Clínicas, establishing the first Interdisciplinary center of specialties in our country. This group was destined to study and research in stereotaxy, in the human encephalon functions and its applications in the epilepsy surgeries, pain, abnormal movements and neuroendocrine abnormalities. In 1974, Dr. Raul Marino Jr. became an Associate Professor.

A multidiscipline team of neurosurgeons, electroencephalogram technicians, engineers, biomedical scientists, neuropsychologists, neurologists, psychiatrists, biochemists, laboratory technicians and specialized nurses was installed. The official inauguration of this Division happened in June of 1977, with the presence of several international scientists including Drs. Walle Nauta, Pedro Molina-Negro, Blaine Nashold, Ayub Ommaya, Thomas Ballantine, Sixto Obrador, Gabor Szikla, Jules Hardy, Jean Sigfried, Gilles Bèrtrand, Philip Gildenberg, John Tew, Laughin Taylor, Heitaro Narabayashi and Theodore Rasmussen, whose presented papers were joined in a book entitled Functional Neurosurgery (Raven Press, New York, 1979) and constituted itself as the first treaty on functional neurosurgery published
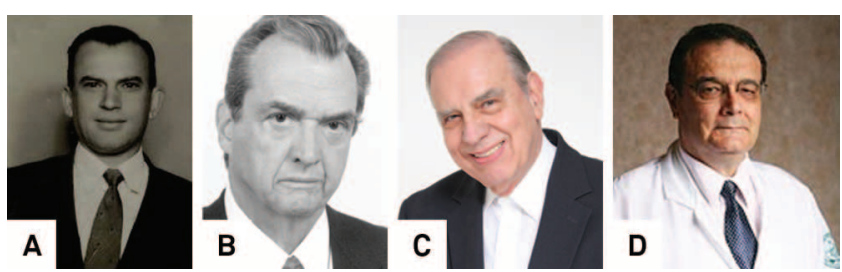

Figure 2. José Zaclis (A), Gilberto Machado de Almeida (B), Raul Marino Júnior (C) and Manoel Jacobsen Teixeira (D). 
in the world medical literature. All the chapters of this recently born specialty were then reunited in a book with 17 chapters.

In the beginning of 1974, Professor Dr. Gilberto Machado de Almeida (Figure 2B), took office as the Head of Neurosurgery Section of the Neurological Clinic. He developed intense work of modernization, being responsible for great advancements in microsurgery and vascular neurosurgery. From 1974 to 1990, he had the intense collaboration of Prof. Dr. José Luzio in directing the residents. Prof. Dr José Luzio was responsible for the education of many neurosurgeons.

It is necessary to emphasize that in the same period there was a great advancement in the care of the patients who had suffered traumatic injuries in the central nervous system under direction of Professor Oswaldo Ricciardi Cruz and Professor Dr. Walter Carlos Pereira.

In April of 1990, was opened a place for Chairman of the Discipline of Neurosurgery, for which applied Professor Dr. Gilberto Machado de Almeida and Professor Dr. Raul Marino Jr.

Once assuming this position, Professor Dr. Raul Marino Jr. (Figure 2C) unified the Division of Functional Neurosurgery with the Division of Neurological Surgery and the Emergency Neurosurgery, in a way to integrate these sectors in a model of cooperative work, achieving more physical space, laboratories and specialized technicians. In this time the Division of Neurological Surgery was settled, in its several subspecialties. In 1998, Professor Dr. Almir Ferreira de Andrade assumed the leadership of the Medical Team of Emergency.

In the year of 1988 was created the Academic League of Migraine and Craniofacial Pain. In 1995 it was created the Academic Multidiscipline League of Pain with the objective to introduce the specialty to the medical students, nursing, physiotherapy, speech therapy areas and occupational therapy, to stimulate the interest for the clinical and experimental. In 1997, was created the Academic League of Neurosurgery,

Professor Dr. Raul Marino Jr retired on March 23 ${ }^{\text {th }}, 2006$. The exam for the new chairman of Neurosurgery took place on March 26 $6^{\text {th }}$, 2007, with the participation of Professor Dr. Guilherme Carvalhal Ribas, Professor Dr. José Pindaro Pereira Plese and Professor Dr. Manoel Jacobsen Teixeira, all with neurosurgical formation carried out in this institution.
Professor Dr. Manoel Jacobsen Teixeira (Figure 2D) was selected as Chairman of the Discipline of Neurosurgery on April $16^{\text {th }}$, 2008, with the cooperation of Professor Dr. José Pindaro Pereira Plese, Professor Dr. Mario Augusto Taricco and Professor Dr. Luis Alcides Manreza. Subsequntely, Dr. Almir Ferreira de Andrade (2005), Dr. Hamilton Matushita (2010), Dr. Eberval Gadelha Figueiredo (2011), Dr. Edson Bor-Seng-Shu (2012), Dr. Erich T. Fonoff (2012), Dr. Roberto Sérgio Martins (2013), Dr. Fernando Campos G. Pinto (2013) and Dr. Guilherme Lepski (2013) obtained the degree of Lecturer-professor. Nowadays, the discipline has three Associate Professors: Professor Dr. Mário Augusto Taricco, Professor Dr. Eberval Gadelha Figueiredo and Professor Dr. Erich Talamoni Fonoff.

Professor Dr. Manoel Jacobsen Teixeira encouraged all the participants of the Disciplines, from the Department of Neurology to the Divisions of Neurological Surgery, Functional Neurosurgery and Institute of Cancer of São Paulo, resulting into many scientific studies and the development of academic and research. In recent years, the Discipline published several scientific papers in indexed journals and organized several examinations for Professorship.

Neurosurgery at USP has been made comparable to the best international Universities, disposing of equipment of intra-operative Magnetic Resonance, Neuronavigation systems, radiosurgery, deep and surface encephalic register and other several edge research projects in basic sciences and clinical and anatomical areas. The internationalization of the Discipline includes three months traineeship for residents in well recognized international institutions. Additionally, in November of 2008, a Joint-Meeting was carried out between the Discipline of Neurosurgery and Barrow Neurological Institute, the institution with the largest number of neurosurgical procedures in North America. Recently, Professor Dr Manoel Jacobsen Teixeira had temporarily held the direction of the Medical Investigation Laboratory of the Discipline of Surgical Technique.

Currently nearly 3000 patients have been operated on in a year, including procedures performed at the two Divisions and in the Cancer Institute of Sao Paulo (ICESP). Six residents are admitted in a year for training. Nowadays, the discipline of neurosurgery of USP forms young surgeons who certainly will become some the future leaders of the brazilian neurosurgery.

\section{REFERENCES}

1. Lange, O. Dados biográficos sobre o Prof. Enjolras Vampré. An Fac Med São Paulo 1938;15:7-33.
2.

Tolosa, A. Clínica Neurológica da Faculdade de Medicina da Universidade de São Paulo: breve notícias de suas atividades durante o período de 1938-1943. Arq Neuropsiquiatr 1994;2:203-210. 